Електронне наукове фахове видання "Ефективна економіка" включено до переліку наукових фахових видань України з питань економіки

(Категорія «Б», Наказ Міністерства освіти і науки України від 11.07.2019 № 975) www. economy.nayka.com.ua | № 4, $2020 \mid 30.04 .2020$ p.

DOI: $\underline{10.32702 / 2307-2105-2020.4 .5}$

УДК 338.467 .6

\author{
В. К. Збарський, \\ д. е. н., професор,
}

Національний університет біоресурсів і природокористування України

ORCID ID: 0000-0002-6114-8602

Д. В. Грибова,

к. е.н, доцент,

Таврійський державний агротехнологічний університет імені Дмитра Моторного

ORCID ID: 0000-0002-3270-2504

\title{
СУЧАСНІ НАПРЯМИ РОЗВИТКУ ТУРИЗМУ В УКРАЇНІ
}

\author{
V. Zbarsky \\ Doctor of Economic Science, Professor, \\ National University of Life and Environmental Sciences of Ukraine \\ D. Gribova \\ PhD in Economics, Associate Professor, \\ Dmytro Motorniy Tavria state agrotechnological university
}

\section{CURRENT DIRECTIONS OF TOURISM DEVELOPMENT IN UKRAINE}

В статті досліджено сучасні особливості функиіонування сфери туризму в Україні. Доведено, щуо сьогоденні темпи приросту кількості туристичних виїздів є прогресуючими, має місие стійке зростання виїзного туризму в Украйні за період 2006-2019 рр. Висвітлено наступні фактори впливу на активізацію виїзного туризму: безвізового режиму з краӥнами ЄC, розширення авіаперевезень та відкриттям прямих авіарейсів, зростання кількості пропозицій низькобюджетних турів, зростання купівельної спроможності українців, зміџнення національної валюти. Доведено, щуо важливою особливістю туристичного бізнесу $\epsilon$ залежність від різких сезонних коливань попиту на туристичний продукт. Для реалізації поставлених завдань пропонуємо використати екстраполяційний підхід та побудувати мультиплікативну модель попиту на виїзний туристичний продукт. Розрахунки показали, щьо виїзний туризм в Украйні має яскраво виражену сезонність. Попит на виїний туристичний продукт суттєво знижується в першому та четвертому кварталах $i$ різко зростає в другому $і$ третьому кварталах року, тобто змінюється в залежності від природно-кліматичного фактору. Дослідження альтернативи відпочинку в Україні та за кордоном показали, щуо за кордоном громадяни України платять майже ту саму суму, щьо й y середині країни. Запропоновано комплекс заходів щэодо забезпечення здешевлення внутрішнього туризму.

The article explores the modern features of tourism in Ukraine. It is noted that there has been a significant development of the tourism industry, but overall trends in the ratio of the three main types of tourism have remained stable.

It is proved that the current rate of increase of the number of tourist departures is progressive, there is a steady increase of the outbound tourism in Ukraine for the period 2006-2019. The 
following factors of influence on the activation of the outbound tourism are highlighted: visa-free regime with EU countries, expansion of air transportation and opening of direct flights the number of offers of low-budget tours, the increase of purchasing power of Ukrainians, the strengthening of the national currency. It is noted that the composition of the top five most popular travel destinations of Ukrainians has remained almost unchanged for the past five years. It is proved that an important feature of the tourism business is the dependence on the sharp seasonal fluctuations in demand for the tourism product. It is noted that the study of seasonality in tourism will not only identify the degree of influence of climatic conditions on the formation of flow of tourists, determine the duration of the tourist season, as well as determine the economic consequences of seasonality at the level of the region and country, as well as to develop a set of measures for seasonal unevenness that affects on the results of the tourism industry.

To accomplish these goals we propose to use an extrapolation approach and build a multiplicative model of demand for an outbound tourist product. The calculations showed that outbound tourism in Ukraine has a pronounced seasonality. Demand for the outbound tourist product declines significantly in the first and fourth quarters and increases sharply in the second and third quarters of the year, it changes depending on the natural and climatic factor. Studies of holiday alternatives in Ukraine and abroad have shown that abroad citizens of Ukraine pay almost the same amount as in the country. A set of measures for providing cheap inland tourism has been proposed.

Ключові слова: туристичний бізнес; сезонний розвиток; виїзний туризм; внутрішній туризм; інфраструктура; інвестиційна привабливість.

Keywords: tourism business; seasonal development; outbound tourism; domestic tourism; infrastructure; investment attractiveness.

Постановка проблеми. За часів незалежності України відбувся значний розвиток туристичної індустрії, проте загальні тенденції співвідношення трьох основних видів туризму залишилися стабільними. Український туристичний ринок завжди демонстрував глибокі диспропорції на користь виїзного туризму, не зважаючи на те, що даний ринковий сегмент пов'язаний з більш високими ризиками. Кращі кон'юнктурні позиції ніж у в'їзного та внутрішнього сектору туризму сформували довгостроковий характер диспропорцій в українській індустрії. Тобто, Україна була і досі залишається донором туристичного потоку. Це обумовлює, 3 метою постійного удосконалення організації та управління туристичною діяльністю на національному та регіональних рівнях, проведення аналізу розвитку даного сектору туризму України.

Аналіз останніх досліджень і публікацій. Необхідно зазначити, що теоретичні та практичні аспекти вітчизняного туристичного бізнесу розглядалися в роботах Л.В. Забуранної, С.В. Кальченко, В.А. Квартальнова, та ін. Разом із цим, на нашу думку, потребують подальшого вивчення сучасні особливості функціонування даної складової національної економіки.

Мета статті - аналіз сучасного стану та специфіки функціонування вітчизняного туристичного бізнесу.

Основні результати дослідження. За даними Держстату з 2006 р. по 2016 р. обсяг виїзного потоку 3 України збільшився у півтора рази (з 16,8 до 24,7 млн подорожей), а з 2006 р. по 2019 р. також у 1,5 рази і становив вже 37,5 млн подорожей. Отже, останні три роки продемонстрували темп росту обсягу виїзного потоку, відповідний сформованим темпам росту попередніх 10 років. Іншими словами, сьогоденні темпи приросту кількості туристичних виїздів є прогресуючими. Спостерігається стійке зростання виїзного туризму в Україні за період 2006-2019 рр. Навіть криза 2008-2009 рр. не змогла переломити цей тренд. Скорочення виїзних потоків було короткостроковим. Наприклад, після 2009 року кількість туристичних подорожей за кордон у 2010 році зросла на 12,4\%. Тобто, вже наступного року після завершення кризи, обсяги виїзного туризму не лише відновлювалися, але й перевищували докризовий рівень за рахунок реалізації «відкладеного» попиту та продовжували зростати у наступні роки.

Тяжкий економіко-політичний період 2014-2015 рр. мав іншу природу, за якого відбувалась повільна динаміка попиту на закордонні тури. Незначний спад туристичного виїзду було зафіксовано у 2014 році на $5,9 \%$. Таким чином, скорочення виїзного туризму майже на 6\% у 2014 році - це єдиний від'ємний темп за останні 10 років (рис. 1). Усього в 2019 році українці здійснили за кордон 28,9 млн подорожей: це майже удвічі більше за показник 2006 року. Лише за останній рік відбулося збільшення громадян, що виїжджали за кордон 3 метою туризму, на 35\%. Зростання імпорту туризму в Україні у 2019 році становило 1,1 млн.

Основними причинами таких показників можна вважати наступні: 
1. Виїзний туристичний потік набирає зростаючу тенденцію у зв'язку з введенням з 11 червня 2017 року безвізового режиму з країнами $\mathrm{CC}$, а також з розширенням лоукост авіаперевезень та відкриттям прямих авіарейсів.

2. Зростання кількості пропозицій низькобюджетних турів. Середня вартість турпакетів зменшилась, що збільшило попит на масові напрямки.

3. Хоча середній рівень грошових доходів домогосподарства України у 2018 році становив 8903,8 грн, порівняно з показником 2017 року, він збільшився на 24,6\%, індекс споживчих цін збільшився на 10,9\%, а величина споживчих сукупних витрат домогосподарства - на 15,2\%. Це можна охарактеризувати як зростання купівельної спроможності українців. Такий стан також позитивно вплинув на споживчий попит на виїзні тури, збільшивши темпи його зростання.

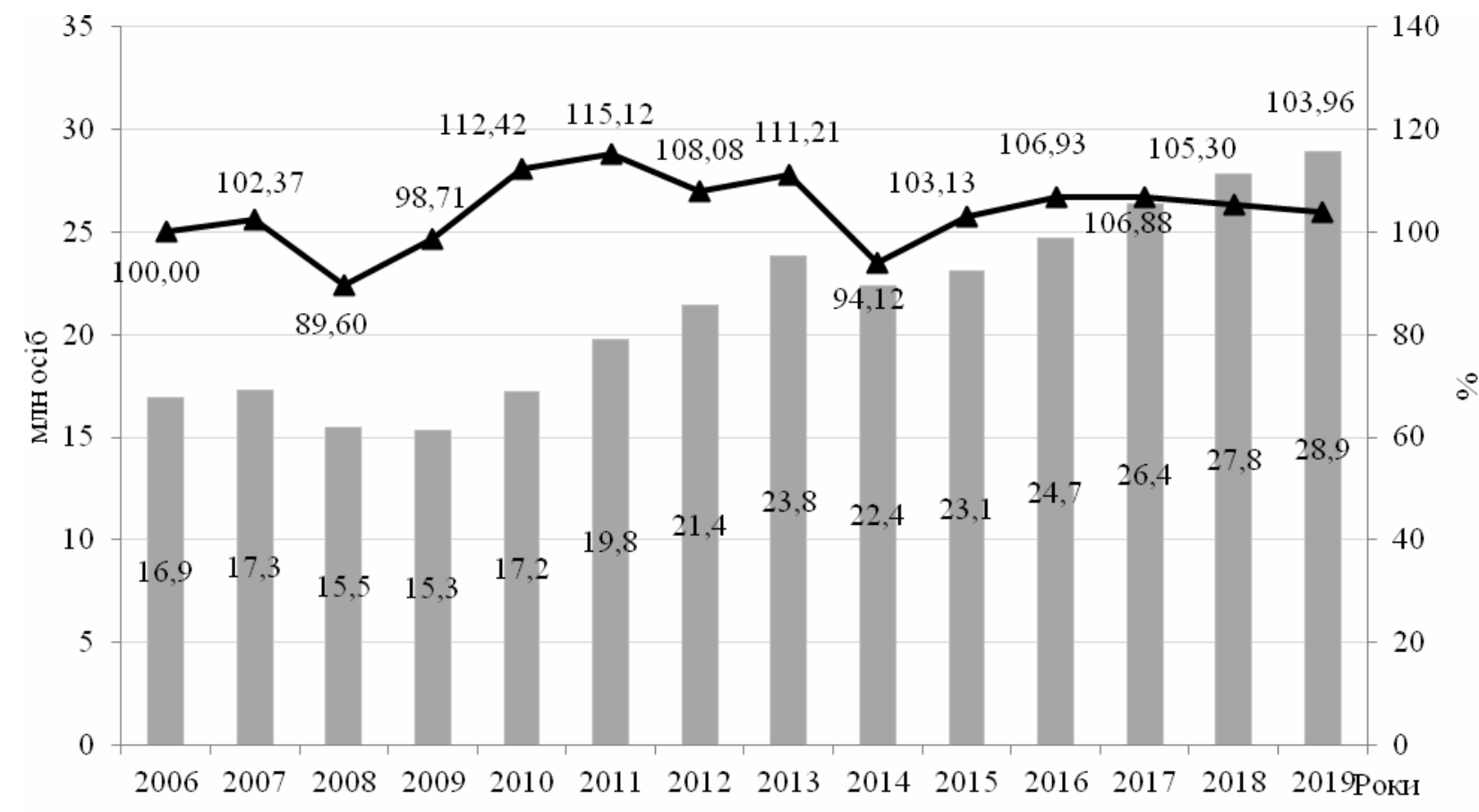

обсяг внїзного потоку, млн - темпн зростання обсягу виїзного потоку, \%

Рис. 1. Динаміка кількості подорожей українців за кордон

Джерело: розраховано та побудовано за даними [12, 13]

4. Зміцнення курсу національної валюти у 2019 році. Укріплення гривні призвело до здешевлення середнього обмінного курсу долара США та євро.

Склад лідируючої п'ятірки найпопулярніших напрямків подорожей українців залишається останні п’ять років майже незмінним. Рейтинг очолює Сгипет - 1290,1 тис туристичного прибуття з України (46,7\%) [13]. При цьому динаміка турпотоку з України в цю країну зростає щороку. Лише за останній рік приріст від’іжджаючих громадян в Сгипет становив 54,3\%. Головні причини - це цінова доступність даного напрямку, велика кількість «гарячих» турів зі знижкою, а також безсезонний курортний клімат.

Туреччина за підсумками 2018 року займає друге місце. Потік українських туристів у Туреччину становив 986,1 тис подорожей, зростання за рік - лише 0,6\% [13]. Тобто, популярність даного туристичного напрямку спадає. Причина - подорожчання на 15-20\% вартості відпочинку в країні. Турецький ціновий стрибок пов'язаний з тим, що готелі перевели розрахунки цін з доларів США на євро, як результат - відпочинок у гривні став дорожчим.

Ще один лідируючий напрямок - Іспанія, третє місце (88,6 тис подорожей). Несприятливі політичні події в Каталонії зробили цей турпоток меншим. Однак, головним фактором залишається інтерес до країни як до туристичного центру Свропи. Відновили свої позиції Німеччина та Італія: дані напрямки зросли на 55,1\% та 65,1\% відповідно. Ці країни впевнено нарощують чисельність прибуття з України.

Взагалі переважно громадяни України виїжджають до прикордонних країн, частка яких з 2016 року поступово зменшується з 88\% до 77\% туристичного потоку [13]. Зменшилося відвідування таких країн як Польща, Угорщина, Молдова, Білорусь, Румунія, Словаччина та Росія. Перерозподіл туристичних потоків пояснюється запровадженням безвізового режиму з країнами ЄС. За даними Адміністрації Державної прикордонної служби, на початок червня 2019 року, за підсумками другого року дії безвізи з СС, кількість українців, що відвідали Свропу за біометричним паспортом, зросла у 4,2 рази та становила 2,35 млн чоловік [14]. 
Спостерігаються якісні зміни в структурі виїзного туристичного потоку до не прикордонних країн. Так зафіксовано суттєве зростання потоків до: Австрії - на 157\%, Болгарії - 42,4\%, Греції - 43,8\%, Кіпру - 23,6\%, Грузії - 18,4\% [13]. Відміна шенгенських віз також зумовила прихід у країну лоукост-авіакомпаній, що в сукупності зробило дешевше подорожі українців до СС та розширило їх географію.

Важливою особливістю туристичного бізнесу є залежність від різких сезонних коливань попиту на туристичний продукт. Вивчення сезонності в туризмі дозволить не лише виявити ступінь впливу природнокліматичних умов на формування потоку туристів, встановити тривалість туристичного сезону, а також визначити економічні наслідки сезонності на рівні регіону та країни, а також розробити комплекс заходів щодо сезонної нерівномірності, яка впливає на результати діяльності туристичної галузі.

Базою для дослідження були статистичні дані Адміністрації Державної прикордонної служби України щодо кількості фактів перетинання державного кордону громадянами України на виїзд з країни у 2014-2019 роках. В основу аналізу було покладено трендове моделювання оцінки варіаційних та динамічних характеристик виїзного турпотоку. Даний аналітичний підхід дозволить виявити підсумковий вектор впливу факторів на ринок виїзного туристичного продукту, наскільки впевнено почуває себе даний вид туризму в Україні і куди він рухається.

Для реалізації поставлених завдань пропонуємо використати екстраполяційний підхід та побудувати мультиплікативну модель попиту на виїзний туристичний продукт наступного вигляду:

$$
Y i=T i \cdot C i \cdot \varepsilon i,
$$

де $Y i$ - обсяг попиту в $i$-тому періоді;

$T i$ - абсолютні значення лінійного тренду в $i$-тому періоді;

$\mathrm{Ci}-$ відносні значення сезонних коливань попиту в $i$-тому періоді;

$\varepsilon i-$ відносні значення випадкових коливань попиту в $i$-тому періоді.

Для розрахунку впливу сезонної компоненти розрахуємо індекси сезонності - відсоткові відношення середніх місячних рівнів за ряд років до загального середньомісячного обсягу виїздів громадян за весь розрахунковий період. Розрахунки показали, що виїзний туризм в Україні має яскраво виражену сезонність (рис. 2). На основі даних рис. 2 можна прийти до висновку про те, що попит на виїзний туристичний продукт суттєво знижується в першому та четвертому кварталах і різко зростає в другому і третьому кварталах року, тобто змінюється в залежності від природно-кліматичного фактору.

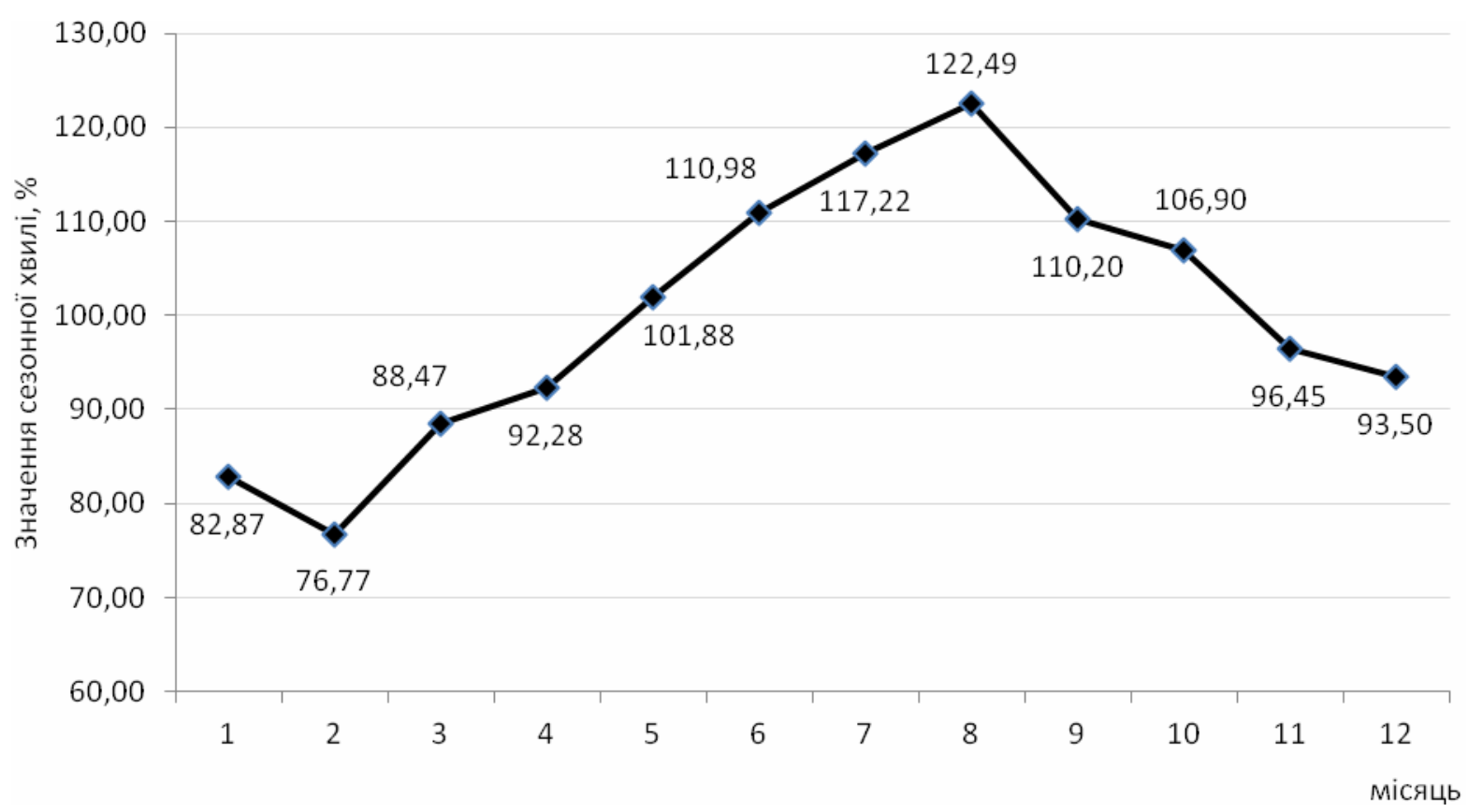

Рис. 2. «Сезонна хвиля» виїзного туризму в Україні у 2014-2019 роках

Джерело: розраховано та побудовано за даними Держсавного управління статистики Украӥни

Сезонний пік виїжджаючого туризму припадає на червень, липень та серпень. Максимальний попит спостерігається в серпні місяці, середній індекс сезонності в якому становив 122,5\%, що на $22,5 \%$ більше загального середнього значення попиту за 2014-2019 роки. Мінімальне значення попиту спостерігається в лютому, середньомісячний індекс сезонності в якому дорівнював 76,8\%, що на 23,2\% менше середнього значення попиту за досліджуваний період. Незначні обсяги реалізації туристичних послуг характерні для зимових та весняних місяців. 
Отримані дані засвідчують розповсюджене уявлення про високий сезон в туризмі - літо. Безперечно, що влітку 3 найбільш сприятливими умовами для рекреаційної діяльності і спостерігається найбільший потік туристів. Однак сезонність у туризмі визначається не лише впливом природних умов, але й соціально-економічними факторами. У першу чергу, це структура споживання товарів і послуг, формування пропозицією платіжоспроможного попиту, наявність вільного часу (масові відпустки, шкільні та студентські канікули) тощо. Крім того, сезонність попиту залежить також і від виду туризму. Найбільш яскраво сезонні процеси виявляються у курортному та гірничо-лижньому напрямках та менш помітні у діловому та екскурсійно-пізнавальному туризмі.

На нашу думку, отримані результати засвідчують занадто високу частку закордонних турів влітку, враховуючи наявність власної альтернативи - санаторно-курортної зони Півдня України. Враховуючи власний туристичний потенціал країни, сезонна поведінка українців, виїжджаючих за кордон, формує негативні наслідки для економіки країни. 3 метою встановлення майбутньої поведінки виїзного туризму, як економічного процесу, за допомогою існуючих універсальних моделей визначено тренд сезонності даного виду туризму України (рис. 3).

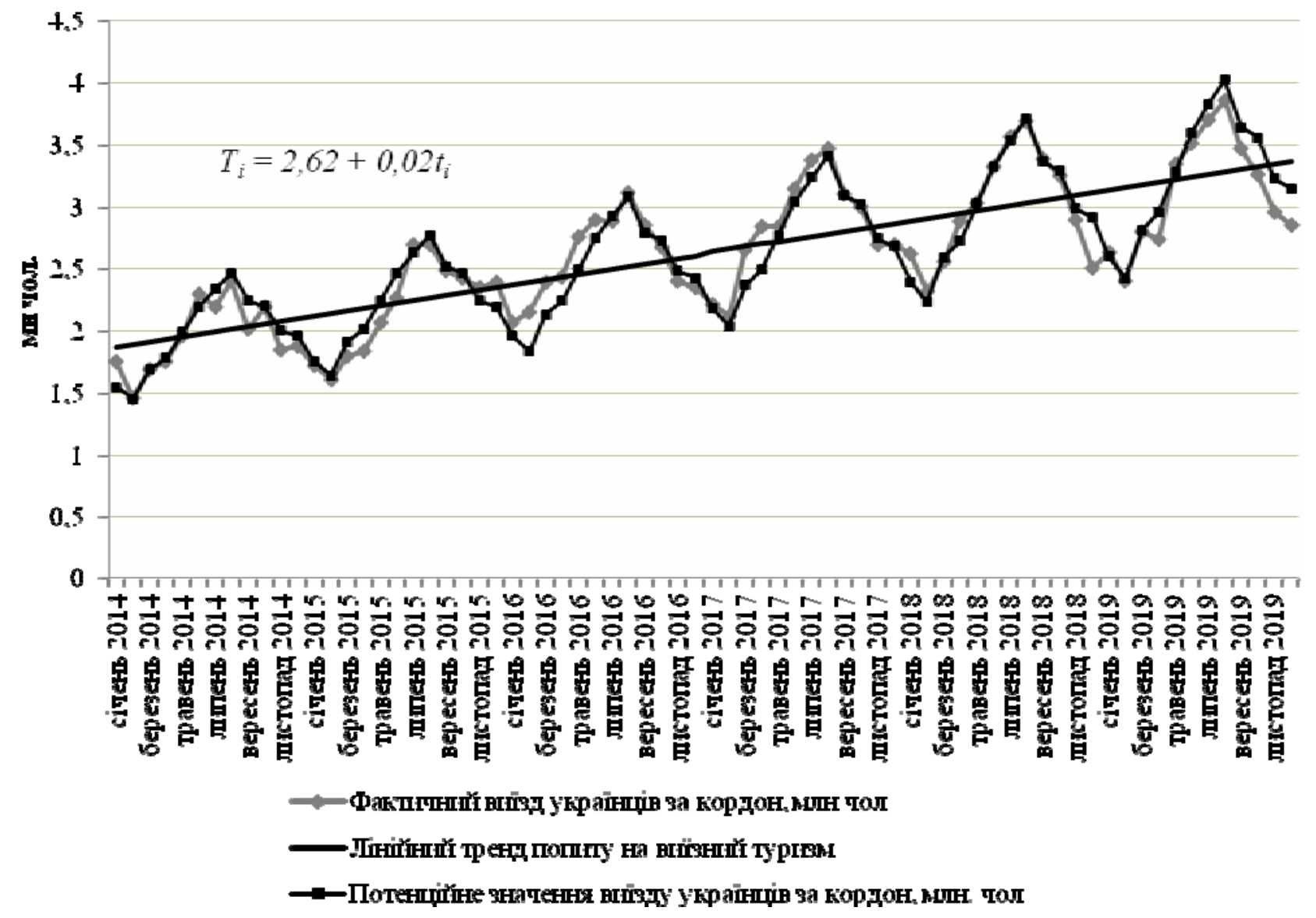

Рис. 3. Результати мультиплікативного трендового моделювання попиту на виїзний туризм в Україні Джерело: розраховано та побудовано за даними Державного управління статистики Украӥни

Як лінійний, так і вирівняний з врахуванням сезонності тренд виїзного туризму демонструє стійку зростаючу тенденцію 3 аналогічним річним циклом. Це засвідчує необхідність удосконалення пропозиції внутрішнього туризму в країні, особливо в період підвищеної активності українських туристів. I першим напрямком такого удосконалення має бути збалансування показників ціна-якість у галузі туризму в Україні. Констатуємо, що, на жаль, високі внутрішні ціни є перепоною для зростання кількості подорожей українців в середині країни. Наведемо наступні факти. В цілому по Україні у 2019 році ціни зросли на 4,1\% [15]. При цьому туристична сфера демонструє більш інтенсивний стрибок внутрішніх цін. Наприклад, вартість розміщення у готелях у середньому по країні у 2019 році, порівняно з 2018 роком, зросла на 8,8\% [15]. Досить активно зростали ціни і на відпочинок у курортно-санаторних зонах.

Підрахунок альтернативи відпочинку в Україні та за кордоном показав, що за кордоном громадяни України платять майже ту саму суму, що й у середині країни. Середньостатистична вартість відпочинку людини на тиждень за кордоном становить 15600 грн (600 дол.), в Україні від 10 до 15 тис. грн, і це без включення у турпакет перельоту, трансферту, системи all inclusive, медичного страхування.

Дуже добре продаються закордонні тури на літо за раннім бронюванням. Останні кілька років ці програми рекламують туристичні оператори, що призводить до зростання попиту на виїзний туризм. Під час раннього бронювання ціни на відпочинок нижчі приблизно на 30\%, є можливість забронювати будь-який готель і оплатити тур частинами. 
На зростання попиту впливає й зміцнення гривні, яке розпочалося в першому півріччі 2019 року. Наприклад, якщо офіційний курс НБУ на 1 січня становив 27,68 грн за долар, то на 1 липня - 24,85 грн за долар.

Також тури по Україні є дорогими в наслідок недешевих транспортних послуг. Ціни на транспортні послуги у 2019 році зросли на 7,7\%, на залізничний пасажирський транспорт - на 19,2\%, на автодорожній пасажирський транспорт - на 7,2\% [15]. Так вартість подорожі з Києва до курортного Бердянська коштуватиме в плацкартному вагоні - від 189 грн, купейному - від 339 грн. При цьому кількість плацкартних місць постійно скорочується, а якість купейних не покращується. Автобусний транспорт ще дорожче - біля 660 грн, а ціна авіасполучення Київ-Запоріжжя взагалі починається з 1140 грн. За умов великої кількості дешевих подорожей до Туреччини, Греції, Грузії, Сгипту зацікавити громадян турами по Україні непросто.

Очевидно, що здешевлення перевезення призведе до зростання попиту на внутрішній туризм. Необхідно приймати заходи на рівні держави, регулюючи ціни, інфраструктуру та сервіс Укрзалізниці та ціни на енергоносії на внутрішніх перевезеннях або через податкові пільги для транспортних компаній-лоукостерів. Автомобільний та автобусний транспорт, з врахуванням стану доріг є також проблематичним. Тому уряду слід зайнятися більш активним будівництвом автобанів та прилеглої інфраструктури по всій країні.

Висновки. Доведено, що сьогоденні темпи приросту кількості туристичних виїздів є прогресуючими, має місце стійке зростання виїзного туризму в Україні за період 2006-2019 рр. Висвітлено наступні фактори впливу на активізацію виїзного туризму: безвізового режиму з країнами СС, розширення авіаперевезень та відкриттям прямих авіарейсів, зростання кількості пропозицій низькобюджетних турів, зростання купівельної спроможності українців, зміцнення національної валюти. Доведено, що важливою особливістю туристичного бізнесу є залежність від різких сезонних коливань попиту на туристичний продукт.

Для реалізації поставлених завдань пропонуємо використати екстраполяційний підхід та побудувати мультиплікативну модель попиту на виїзний туристичний продукт. Розрахунки показали, що виїзний туризм в Україні має яскраво виражену сезонність. Попит на виїзний туристичний продукт суттєво знижується в першому та четвертому кварталах і різко зростає в другому і третьому кварталах року, тобто змінюється в залежності від природно-кліматичного фактору. Дослідження альтернативи відпочинку в Україні та за кордоном показали, що за кордоном громадяни України платять майже ту саму суму, що й у середині країни. Запропоновано комплекс заходів щодо забезпечення здешевлення внутрішнього туризму.

\section{Список використаних джерел.}

1. Світовий атлас даних. URL https:/knoema.ru/atlas/Весь мир/Туризм (дата звернення 02.02.2020).

2. World Tourism Barometer. URL https://www.unwto.org/publication/unwto-world-tourism-barometer-andstatistical-annex-may-2019 (дата звернення 02.02.2020).
3. UNWTO
Tourism
Highlights
2018
Edition.
URL
https://www.eunwto.org/doi/pdf/10.18111/9789284419876 (дата звернення 02.02.2020).

4. Путешествия, туризм, гостиничный бизнес. Экономический вклад туризма и путешествий в ВВП по всему миру 2006-2018: URL https://www.statista.com/statistics/233223/travel-and-tourism--total-economiccontribution-worldwide/ (дата звернення 02.02.2020).

5. Інформація щодо відвідування України іноземцями та виїзду громадян України за кордон (2015-2018 роки) (за даними Адміністрації Державної прикордонної служби). URL https://www.me.gov.ua/Documents/Detail?lang=uk-UA\&id=3ba262e6-1603-4090-b741-

e3c47a7f6d71\&title=InformatsiiaSchodoVidviduvanniaUkrainiInozemnimiTuristamiTaViizduGromadianUkrainiZaKor donZaIPivrichchia2016-2017-Rokiv\&isSpecial=true (дата звернення 02.02.2020).

6. Інформація щодо показників розвитку сфери туризму та курортів у 2016 році. URL https://www.me.gov.ua/Documents/Detail?lang=uk-UA\&id=5badba79-

cfc540c1a1ec61f2e39161aa\&title=InformatsiiaSchodoPokaznikivRozvitkuSferiTurizmuTaKurortivU2016-Rotsi (дата звернення 02.02.2020).

7. Individual country/economy profiles and additional features of the report are available online / The Travel \& Tourism Competitiveness Report 2019 URL: http://reports.weforum.org/ttcr. (дата звернення 02.02.2020).

8. UNWTO Tourism Highlights, 2017 Edition. URL: http://tourlib.net/wto/WTO highlights 2017.pdf. дата звернення 02.02.2020).

9. UNWTO Tourism Highlights, 2015 Edition. URL: http://tourlib.net/wto/WTO_highlights_2015.pdf. (дата звернення 02.02.2020).

10. UNWTO Tourism Highlights, 2013 Edition. URL:http://tourlib.net/wto/WTO_highlights_2013.pdf. дата звернення 02.02.2020).
11. Туризм.
Кількість
засобів
розміщення
2018
рік.
URL https://vuzlit.ru/378030/rozvitok_gotelnogo_gospodarstva_ukrayini (дата звернення 02.02.2020).

12. Туризм. Виїзд громадян України за кордон, до яких вони виїжджали. URL: https://www.me.gov.ua/Documents/List?lang=uk-UA\&id=be44a1a7-69b3-4a77-a86a447499abcdd6\&tag=Analitika\&isSpecial=true (звернення 02.02.2020).

13. Туризм /Аналітика та статистика. Інформація щодо відвідування Україниіноземними туристами та виїзду громадян України за кордон 2016-2019 роки. Департамент туризму та курортів Міністерства розвитку економіки, торгівлі та сільського господарства України URL: https://me.gov.ua/Documents/List?lang=ukUA\&id=be44a1a7-69b3-4a77-a86a-447499abcdd6\&tag=Analitika (дата звернення 02.02.2020). 
14. Результати оперативно-службової діяльності Держприкордонної служби. Інфографіка 2017-2019 роки - державна прикордонна служба України. URL: https://dpsu.gov.ua/ua/activity/ohorona-kordonu/ (дата звернення 02.02.2020).

15. Індекси споживчих цін на товари і послуги. Ціни. Статистична інформація. Державна служба статистики України: URL: http://www.ukrstat.gov.ua/ (дата звернення 02.02.2020).

16. Забуранна Л.В. Зарубіжний досвід розвитку сільського зеленого туризму. Економіка АПК. 2011. № 6. C.178-183.

17. Кальченко С.В., Демко В.С. Стратегічні напрямки розвитку туристичної галузі в Запорізькій області. Збірник наукових праць ТДАТУ (економічні науки). 2019. №1. С.121-128.

18. Квартальнов В.А. Туризм. Учебник. М.: Финансы и статистика. 2002. 320 с.

\section{References.}

1. Knoema (2020), “World Data Atlas”, available at: https://knoema.ru/atlas/Весьмир/Туризм (Accessed 2 February 2020).

2. UNWTO (2019), "World Tourism Barometer", available at: https://www.unwto.org/publication/unwtoworld-tourism-barometer-and-statistical-annex-may-2019. (Accessed 2 February 2020).

3. UNWTO (2019), "Tourism Highlights 2018 Edition", available at: https://www.eunwto.org/doi/pdf/10.18111/9789284419876. (Accessed 2 February 2020).

4. Statista (2019), "Travel, Tourism, Hospitality. Economic Contribution of Tourism and Travel to GDP Worldwide 2006-2018”, available at: https:/www.statista.com/statistics/233223/travel-and-tourism--total-economiccontribution-worldwide/ (Accessed 2 February 2020).

5. Ministry for Development of Economy, Trade and Agriculture of Ukraine (2019), "Information on the visit of foreigners to Ukraine and the departure of Ukrainian citizens abroad (2015-2018) (according to the data of the State Border Service)", available at: https:/www.me.gov.ua/Documents/Detail?lang=uk-UA\&id=3ba262e6-1603-4090b741-

e3c47a7f6d71\&title=InformatsiiaSchodoVidviduvanniaUkrainiInozemnimiTuristamiTaViizduGromadianUkrainiZaKor donZaIPivrichchia2016-2017-Rokiv\&isSpecial=true (Accessed 2 February 2020).

6. Ministry for Development of Economy, Trade and Agriculture of Ukraine (2017), "Information on tourism and resort development indicators in 2016", available at: https://www.me.gov.ua/Documents/Detail?lang=ukUA\&id=5badba79-

cfc540c1a1ec61f2e39161aa\&title=InformatsiiaSchodoPokaznikivRozvitkuSferiTurizmuTaKurortivU2016-Rotsi

(Accessed 2 February 2020).

7. World Economic Forum (2019), “The Travel \& Tourism Competitiveness Report 2019”, available at: http://reports.weforum.org/ttcr (Accessed 2 February 2020).

8. UNWTO (2018), "UNWTO Tourism Highlights, 2017 Edition", available at: http://tourlib.net/wto/WTO_highlights 2017.pdf (Accessed 2 February 2020).

9. UNWTO (2016), "UNWTO Tourism Highlights, 2015 Edition", available at: http://tourlib.net/wto/WTO_highlights_2015.pdf. (Accessed 2 February 2020).
10. UNWTO
(2014),
"UNWTO Tourism
Highlights,
2013 Edition", available at: http://tourlib.net/wto/WTO_highlights 2013.pdf. (Accessed 2 February 2020).

11. vuzlit.ru (2019), "Tourism. Number of accommodation units 2018", available at: https://vuzlit.ru/378030/rozvitok_gotelnogo_gospodarstva_ukrayini (Accessed 2 February 2020).

12. Ministry for Development of Economy, Trade and Agriculture of Ukraine (2020), "Tourism. Departure of Ukrainian citizens abroad", available at: https://www.me.gov.ua/Documents/List?lang=uk-UA\&id=be44a1a7-69b34a77-a86a-447499abcdd6\&tag=Analitika\&isSpecial=true (Accessed 2 February 2020)

13. Ministry for Development of Economy, Trade and Agriculture of Ukraine (2020), "Tourism. Analytics and statistics. Information on foreign tourists visiting Ukraine and traveling abroad 2016-2019. Department of Tourism and Resorts of the Ministry of Economic Development, Trade and Agriculture of Ukraine", available at: https://me.gov.ua/Documents/List?lang=uk-UA\&id=be44a1a7-69b3-4a77-a86a-447499abcdd6\&tag=Analitika

(Accessed 2 February 2020)

14. State Border Guard Service of Ukraine (2020), "Results of the Operational and Service Activity of the State Border Guard Service. Infographic 2017-2019”, available at: https://dpsu.gov.ua/ua/activity/ohorona-kordonu/ (Accessed 2 February 2020)

15. State Statistics Service of Ukraine (2020), "Consumer price indices for goods and services. Prices. Statistical information”, available at: http://www.ukrstat.gov.ua/ (Accessed 2 February 2020)

16. Zaburanna, L.V. (2011), "Foreign experience in the development of rural green tourism", APK economy, vol. 6, pp.178-183.

17. Kal'chenko S.V. and Demko V.S. (2019), "Strategic directions of tourism industry development in Zaporizhzhya region", Proceedings of the TDATU (Economic Sciences), vol.1, pp.121-128.

18. Kvartal'nov, V.A. (2002), Turizm [Tourism], Finance and statistic, Moscow, Russian. 